\title{
First description of the female of the spider Savignia zero Eskov, 1988 (Araneae: Linyphiidae)
}

\author{
LIANA LASUT ${ }^{1,2}$, YURI M. MARUSIK ${ }^{3} \&$ HOLGER FRICK ${ }^{1,2,4}$ \\ ${ }^{1}$ University of Bern, Institute of Ecology and Evolution, Baltzerstrasse 6, 3012 Bern, Switzerland \\ ${ }^{2}$ Natural History Museum Bern, Bernastrasse 15, 3005 Bern, Switzerland \\ ${ }^{3}$ Institute for Biological Problems of the North, Portovaya Str. 18, Magadan, Russia \\ ${ }^{4}$ Corresponding author: E-mail: holger.frick@gmx.li
}

Savignia is a relatively large and well defined Holarctic spider genus (see Eskov 1988). It includes 23 species, of which seven are known by males only (Platnick 2009). Thirteen species, including many endemics, have been recorded from the Far East Palaearctic (Eskov 1991).

While studying collections of the Senckenberg Museum Frankfurt we found one sample that contained males and previously unknown females of $S$. zero Eskov, 1988. The aim of this paper is to provide an illustrated description of the female including detailed comparisons with S. birostra (Chamberlin \& Ivie, 1947) and S. saitoi Eskov, 1988. These species (together with $S$. nenilini Marusik, 1988) were considered as most similar to $S$. zero by Eskov (1988) and all four occur in the Far East Palaearctic.

Specimens were examined and illustrated in $80 \%$ ethanol or glycerol gelatine $\left(\mathrm{C}_{3} \mathrm{H}_{8} \mathrm{O}_{3}\right)$ using a Leica MZ18 stereo microscope and an Axioplan 2 compound microscope, both equipped with a camera lucida. Colour descriptions refer to Pantone $^{\mathrm{TM}}$ Color Formula Guide on uncoated paper. Scanning electron micrographs were taken with a JEOL JSM-5200 in the Zoological Museum, University of Turku. All measurements are in mm.

\section{Savignia zero (Eskov, 1988)}

(Fig. 9-20)

Savignia zero Eskov, 1988: 34, figs 83-85 (Dふ̂).

HOLOTYPE: Russia: Magadan: middle Chelomdzha river (left tributary of Taui river), 1ð, vi.-viii.1987 (N.E. Dokutchaev; not examined, due to the distinctive male carapace).

Examined material. Russia: Magadan: Ola river mouth, $8 \hat{\jmath}$ 14 , 18.ix.1990 (Y.M. Marusik, SMF 39671). Khabarovsk province: environment of Bychikha village, Bolshekhektsyrski reserve, "Klyuch Sosnenskiy" kordon, circa $430 \mathrm{~m}$, tall grass and carex along creek valley formed by boulders [48 14'33"N, 13447'00"E], $7 \overbrace{}^{\circ} 13$, $14 . i x .2005$ (Y.M. Marusik, IBPN); environment of Khabarovsk, environment of Bychikha village, Bolshekhektsyrski reserve, secondary

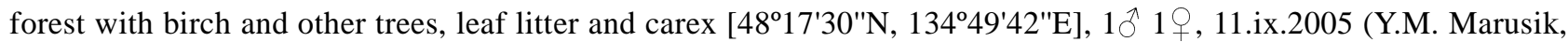
IBPN).

Examined comparative material: $S$. birostra: USA: Alaska: Kodjak island, Dog Salmon river [57 $11^{\prime} 49^{\prime \prime} \mathrm{N}$, $154^{\circ} 02^{\prime} 08^{\prime \prime W}$ ], $5{ }^{\Uparrow} 5$ (NMBE 6744). S. saitoi: Russia: Sakhalin: Sakhalin island, southeast port, Mereya river circa 3 km from mouth, [46³8'46.4"N, 14254'16.1"E], 4ㅇ, 28.vii.2001 (Y.M. Marusik. IBPN). Sakhalin: Kunashir island, Otrandnoye, 1̧̂, 19.ix.1987 (A.M. Basarukin, ZMMU). Six examined paratype females (Russia: Amur: Khingan state reserve, gramineous meadow, 2 , $01 . v i i i .1983$ (Y.M. Marusik, IBPN). Sakhalin: Kunashir island, Otrandnoye, 49, 19.ix.1987, (A.M. Basarukin, ZMMU)) that were mentioned in Eskov (1988) are not conspecific with topotype females from Sakhalin and their belonging is unclear.

Diagnosis. Males are best distinguished from other Savignia species by its arch-like PME-lobe and the frontally protruding AME-lobe, which both are covered with stout hairs frontally (Eskov 1988: fig. 83). Male cephalic lobes of all Savignia species are species specific (e.g. see figures in Eskov 1988). The embolic division and especially the margin of 
the transparent outgrowth is species specific but difficult to differentiate without comparative material or a compound microscope, respectively (Figs 4, 8, 12). The embolus is sigmoid in S. zero and S. saitoi (Figs 8, 12), but straight and most sclerotised in S. birostra (Fig. 4). Females can be separated from similar species by the more robust and simpler epigynum with rounded, instead of pointed, anterior tips (Figs 1-3, 5-7, 9-11) and seen in lateral view, its square (Figs 11,20 ) rather than triangular shape (Figs 3, 7, 23). In addition, the presence of two pits of the ventral plate, seen in aboral view (Fig. 19), is also diagnostic. The tibial spine formula is $2211 \mathrm{in}$ S. zero and S. saitoi and 0000 in S. birostra (instead bare strip in both sexes).

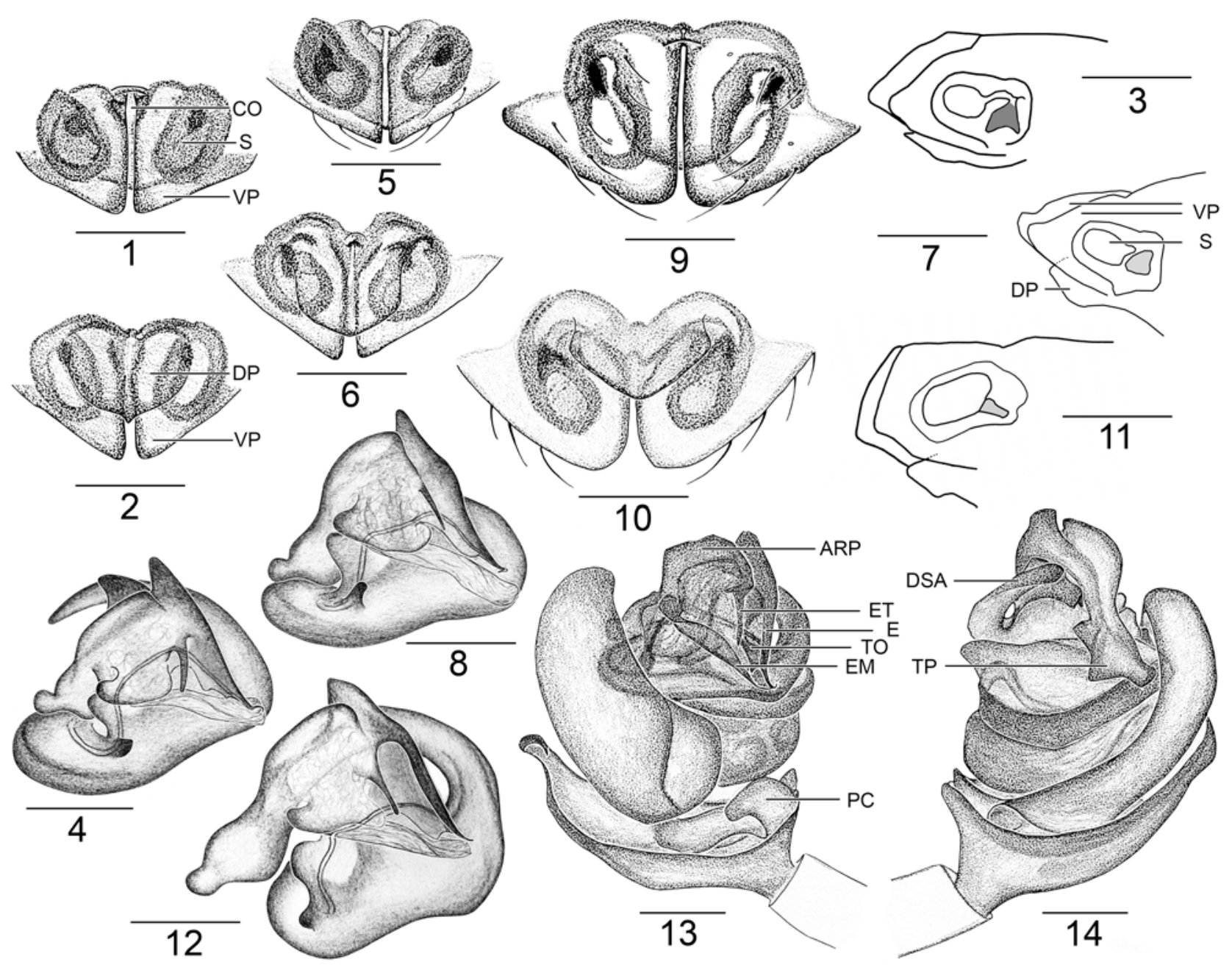

FIGURES 1-18. Savignia birostra (1-4), S. saitoi (5-8), S. zero (9-14). Epigynum, ventral (1, 5, 9), dorsal (2, 6, 10), lateral $(3,7,11)$. Embolic division dorsal (4, 8, 12). Male palp, retrolateral (13), prolateral (14). Scale bars: $0.1 \mathrm{~mm}$. Abbreviations: ARP: anterior radical process, CO: copulatory opening, DP: dorsal plate, E: embolus, ET: embolic tooth, EM: embolic membrane, DSA: distal suprategular apophysis, PC: paracymbium, S: spermatheca, TO: transparent outgrowth, TP: radical tailpiece, VP: ventral plate.

Description. Males: (SMF 39671, N=8, means in parentheses): colours slightly variable. Total length: 1.49-1.66 (1.58) with cephalic lobe, 1.37-1.54 (1.46) without cephalic lobe. Cephalothorax: dark-brown with slight red or orange (470C); 0.71-0.79 (0.76) long, 0.55-0.64 (0.60) wide. Eyes: PME on PME-lobe above PLE and ALE, AME frontal to it (Eskov 1988: fig. 83). Chelicerae: stridulatory striae imbricated, evenly spaced; six promarginal teeth, four retromarginal denticles. Sternum: brown-green (469C) with black scatters; 0.49-0.54 (0.51) long, 0.44-0.47 (0.45) wide. Legs: honeybrown or orange-yellow (138C); tibial spine formula 2211; TmI: 0.39-0.54 (0.43); leg formula 4-1-2-3. Pedipalp: honeybrown $(138 \mathrm{C})$, patella ratio length/width $=2.1$; tibia with three retrolateral and one prolateral trichobothrium; embolic tip with projection beyond embolic opening (Figs 13, 16), embolus with transparent outgrowth (Fig. 12). Females: (SMF 39671, N=14, means in parentheses): Colours slightly variable. Total length: 1.32-1.57 (1.46). Cephalothorax: dark brown-orange (471C); 0.60-0.70 (0.66) long, 0.49-0.57 (0.54) wide; general appearance as male, but without cephalic lobe. Eyes: posterior row procurved, anterior row straight. Chelicerae: five promarginal teeth, five retromarginal teeth. 
Sternum: brown-green (469C) with black scatters; 0.42-0.50 (0.46) long, 0.39-0.43 (0.41) wide. Legs: yellow (124U); tibial spine formula 2211; TmI: 0.42-0.65 (0.53); leg formula 4-1-2-3. Epigynum: brown-green (469C) without black scatters; ventral plate with round anterior edges (Figs 9, 18), two pits visible in aboral view (Fig. 19), square-shaped in lateral view (Figs 11, 20), not triangular as in the other two species (Figs 3, 7). Spermathecae oval-shaped, parallel to each other.

Distribution. S. zero is restricted to North-eastern Siberia and Russian Far East (Fig. 28) and occurs from eastern Yakutia (Marusik et al. 1993) to northern Cisokhotia around Magadan area (Eskov 1988; Marusik 2005) to Cisamura (Tanasevitch 2006; Marusik et al. 2007). The occurrence in Maritime province mentioned by Tanasevitch (2006) is based on a misidentification.

Habitat. S. zero occurs in wetland and swampy sides, in plant debris and mosses among tussocks (Eskov 1988; Tanasevitch 2006, 2008), in floodplain forests (Marusik 2005) and spruce fir and mixed forests (Marusik et al. 2007).

Phenology. Adults of S. zero were found between June and September (Eskov 1988; Tanasevitch 2006, 2008).

\section{Acknowledgements}

For loans we would like to thank Peter Jäger (Senckenberg Museum Frankfurt, DE; SMF) and for fruitful discussions Christian Kropf and Yvonne Kranz-Baltensperger (both Natural History Museum Bern, CH; NMBE) and two anonymous reviewers and the editor (Gustavo Hormiga, USA) for their valuable comments. This work was supported in part by the RFFI grant \# 09-04-01365-a.
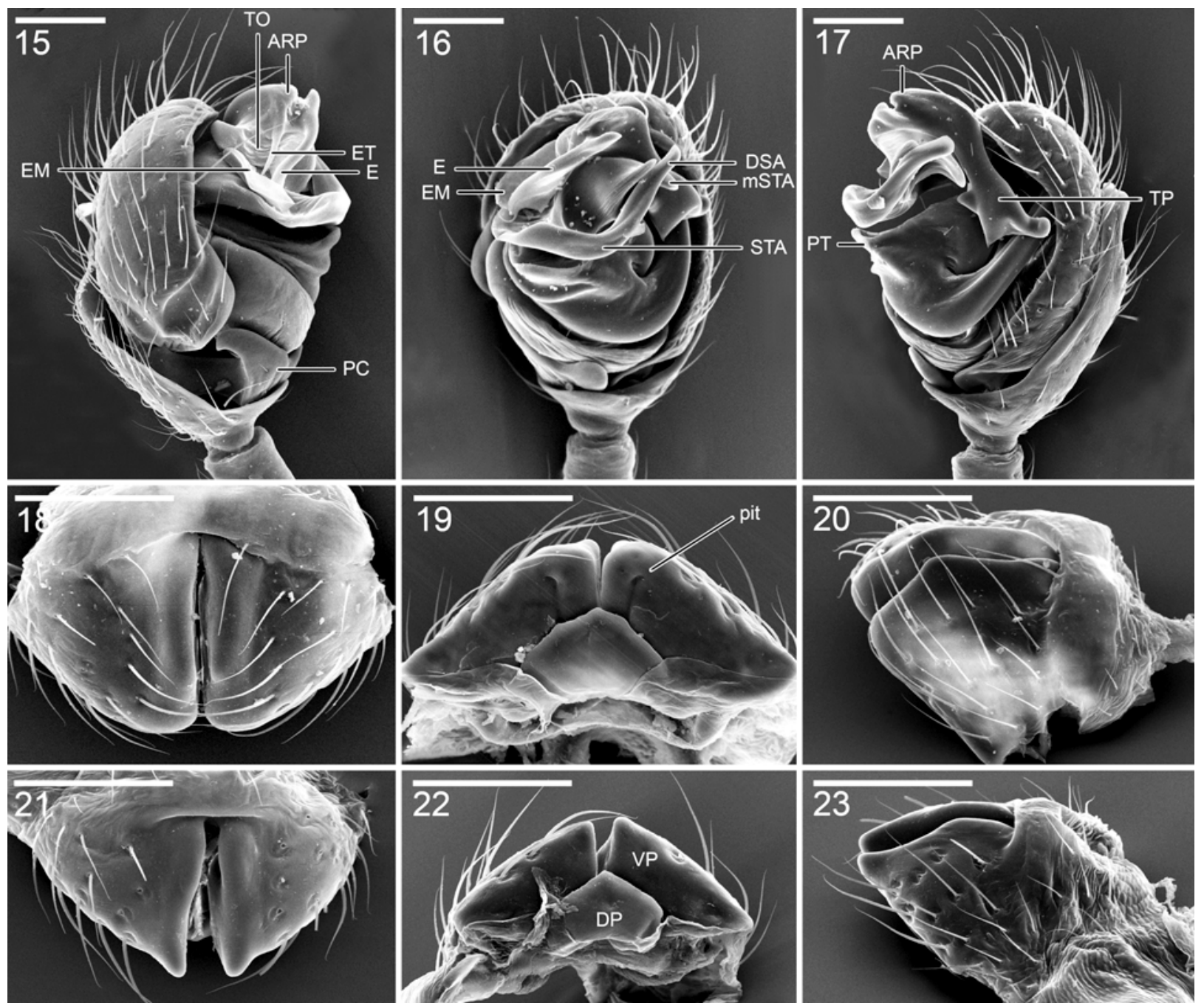

FIGURES 19-27. Savignia zero (15-20) and S. saitoi (21-23). Male palp retrolateral (15), ventral (16), prolateral (17). Epigynum, ventral $(18,21)$, aboral $(19,22)$, lateral (20, 23 mirrored). Scale bars: 0.1 mm. Abbreviations: PT: protegulum, STA: suprategular apophysis, mSTA: mesal suprategular apophysis. 


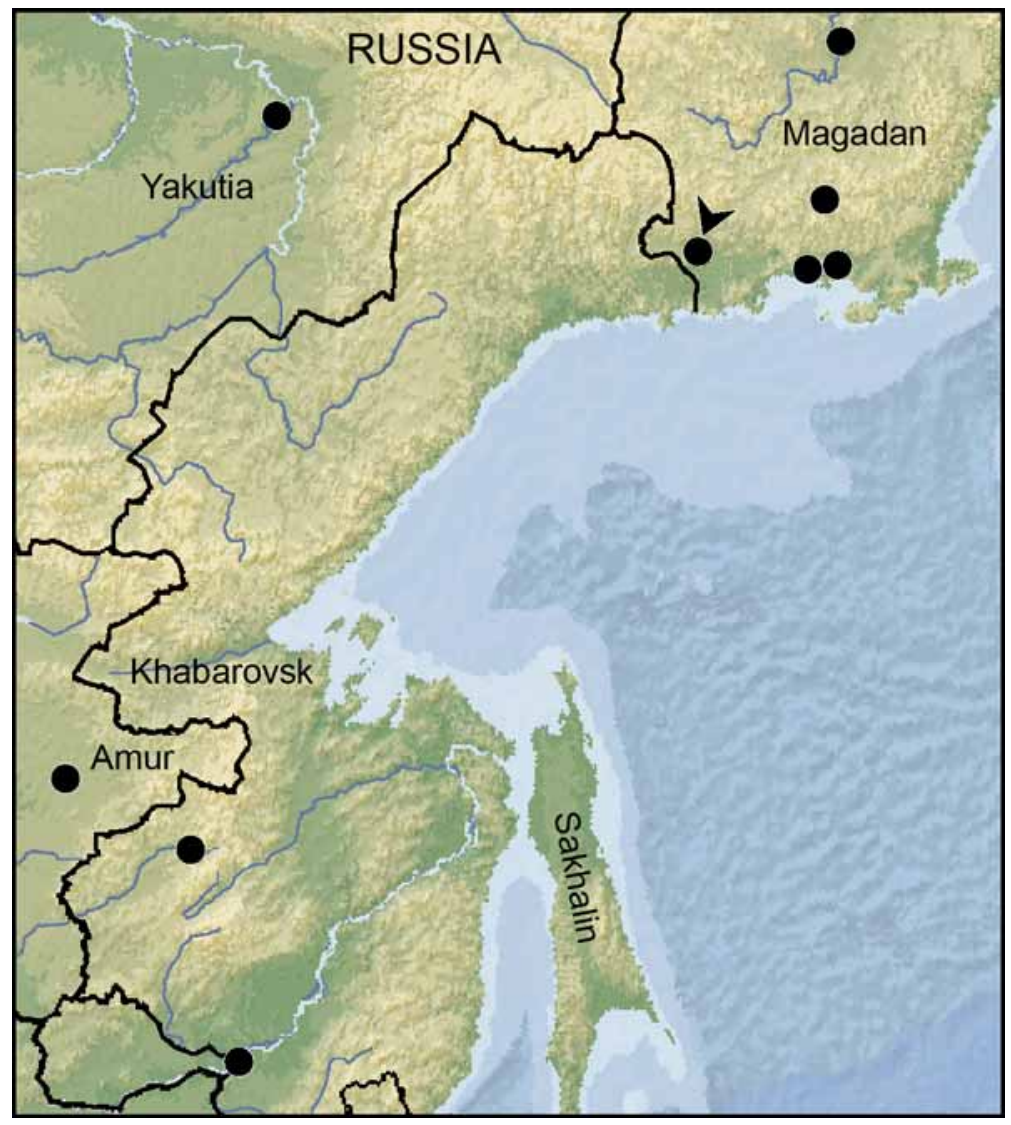

FIGURE 28. Distribution of Savignia zero showing all known localities. The type locality is indicated by an arrow.

\section{References}

Chamberlin, R.V. \& Ivie, W. (1947) The Spiders of Alaska. Bulletin of the University of Utah, 37, 1-103.

Eskov, K.Y. (1988) The spider genera Savignya Blackwall, Diplocephalus Bertkau and Archaraeoncus Tanasevitch (Aranei, Linyphiidae) in the fauna of Siberia and the Soviet Far East. Folia Entomologica Hungarica, 49, 13-39.

Eskov, K.Y. (1991) A spider genus Savignya (s. str.) (Aranei, Linyphiidae) in the fauna of the Far East and central Asia. Zoologichesky Zhurnal, 70, 140-144.

Marusik, Y.M. (1988) Three new spider species of the family Linyphiidae (Aranei) from the north-east of the USSR. Zoologichesky Zhurnal, 67, 1914-1918.

Marusik, Y.M. (2005) Arachnids (Arachnida: Aranei, Opiliones) of northern Cisokhotia. Euroasian entomological journal, 4, 187-208. [in Russian]

Marusik, Y.M., Eskov, K.Y., Koponen, S. \& Vinokurov, N.N. (1993) A check-list of the spiders (Aranei) of Yakutia, Siberia. Arthropoda selecta, 2, 63-79.

Marusik Yu.M., Tanasevitch A.V., Kurenshchikov D.K. \& Logunov D.V. (2007) A check-list of the spiders (Araneae) of the Bolshekhekhtsyrski Nature Reserve, Khabarovsk Province, the Russian Far East. Acta Arachnologica Sinica, 16, 37-64.

Platnick, N.I. (2009) The world spider catalog, version 9.5, American Museum of Natural History. Available from: http:/ /research.amnh.org/entomology/spiders/catalog/index.html (accessed 20 April 2009).

Tanasevitch, A.V. (2006) Linyphiid spiders of the Norsky Nature Reserve, Amurskaya Area, Russian Far East (Arachnida: Aranei). Arthropoda Selecta, 14, 347-371.

Tanasevitch, A.V. (2008) New records of linyphiid spiders from Russia, with taxonomic and nomenclatural notes (Aranei: Linyphiidae). Arthropoda Selecta, 16, 115-135. 